Teeth of Mammals" (Quart. Journ. Micros. Soc., I872); and "On the Domestic Pig in Prehistoric Times"(Trans. Linn. Soc., I877).

Latterly he did much admirable work in anthropology, for which he was excellently qualified, being one of the few men who possess the culture of the antiquary, historian, and philologist on the one hand, and of the anatomist and zoologist on the other, and could make these different branches of knowledge converge upon the complex problems of man's early history. The chief results of his work of this nature are contained in his contribution to Greenwell's "British Barrows" (1877), a book containing a fund of solid information relating to the early inhabitants of this island. In this department of science Prof. Rolleston stood almost alone in this country, and we know of no more fitting tribute which the University of Oxford could pay to his memory than to found a chair of anthropology, a subject in the cultivation of which England is fast being outstripped by every other civilised nation. His last publication, and one which is on the whole the most characteristic as exhibiting his vast range of knowledge on many different subjects, was a lecture delivered in 1879 at the Royal Geographical Society on "The Modifications of the External Aspects of Organic Nature produced by Man's Interference."

That Dr. Rolleston has not left more original scientific work behind him is easily accounted for by the circumstances under which he lived at Oxford. The multifarious nature of the subjects with which the chair was overweighted; the perpetual discussions in which he was engaged consequent upon the transitional condition of education both at Oxford and elsewhere during the whole term of his office; the immense amount of business thrust upon him, or which he voluntarily undertook, of the kind that always accumulates round the few men who are at the same time capable and unselfish, such as questions pertaining to the local and especially the sanitary affairs of the town in which he lived, or connected with the reform of the medical profession, both in and out of the Medical Council, which constantly brought him to meetings in London; his own wide grasp of interest in social subjects, and deep feeling of the responsibilities of citizenship, and his sense of the duties of social hospitality, which made his house always open to scientific visitors to Oxford; all these renfered that intense concentration requisite for carrying out any continuous line of research impossible to him.

$\mathrm{He}$ was often blamed for undertaking so much and such diverse kinds of labour, so distracting to hís scientific pursuits; but being by constitution a man who could never see a wrong without feeling a burning desire to set it right, who could never "pass by on the other side" when he felt that it was in his power to help, nothing but actual physical impossibility would restrain him. For several years past, when feeling that his health and strength did not respond to the strain he put upon them, he resorted to every hygienic measure suggested but one, and that the one he most required, rest; but this he never could or would take. During the last term he spent at Oxford, before his medical friends positively forced him (though unfortunately too late) to give up his occupations and seek change in a more genial climate, he was working at the highest pressure, rising every morning at six o'clock, to get two uninterrupted hours in which to write the revised edition of the "Forms of Animal Life" before the regular business of the day commenced.

It is impossible for those who had no personal knowledge of Rolleston to realise what sort of a man he was, and how great his loss will be to those who remain behind him. No one can ever have passed an hour in his company, or heard him speak at a public meeting, without feeling that he was a man of most unusual power, of lofty sentiments, generous impulses, marvellous energy, and wonderful command of language. In brilliant repartee, aptness of quotation, and ever-ready illustration from poetry, history, and the literature of many nations and many subjects, besides those with which he was especially occupied, he had few equals. "In God's war slackness is infamy" might well have been his motto, for with Rolleston there was no slackness in any cause which he believed to be God's war. $\mathrm{He}$ was impetuous, even vehement, in his advocacy of what appeared to him true and right, and unsparing in denunciation of all that was mean, base, or false. To those points in the faith of his fathers which he believed to be essential he held reverently and courageously, but on many questions, both social and political, he was a reformer of the most advanced type. Often original in his views, always outspoken in giving expression to them, he occasionally met with the fate of those who do not swim with the stream, and was misunderstood; but this was more than compensated for by the affection, adniration, and enthusiasm with which he was regarded by those who were capable of appreciating his nobility of character. The loss of the example aftorded by such a nature, and of his elevating influence upon younger and weaker men, is to our mind a still greater loss, both within and without the University in which he taught, than the loss of what scientific work he might yet have performed.

Dr. Rolleston's personal appearance corresponded with his character. Of commanding height, broad-shouldered, with a head of unusual size, indicating a volume of brain commensurate with his intellectual power, and with strongly-marked and expressive features, in which refinement and vigour were singularly blended, in him we saw just such a man as was described by the public orator at the late Oxford Commemoration, in words with which we may conclude this notice-" Virum excultissimi ingenii, integritatis incorruptissimæ, veritatis amicum, et propugnatorem impavidum."

W. H. F.

\section{THE ZOOLOGICAL SOCIETY'S INSECTARIUM}

$\mathrm{T}$ our notice of this recent addition to the Regent's Park collection (antea, vol. xxiv. p. $3^{8}$ ) we regret to find we have made an error in the name of the curator of the Insectarium. Mr. William Watkins (not E. Watkins as there given) has made many good additions to the collection of living insects under his charge since we last wrote, and attracts a host of visitors every day to inspect his living wonders. In a report on the Insectarium read at a recent scientific meeting of the Zoological Society by the secretary, Mr. Watkins gave the subjoined account of the progress of the developinent of the large moths of the family Bombycidæ during the month of May.

GLOVER'S SILK-MOTH (Samia Gloveri).--Specimens of this species emerged almost daily through the month, and fertile eggs were obtained, which hatched on the I2th instant. The larvæ when hatched are a shining black, with numerous spines of the same colour; after the first change, which took place in six days, they assume a yellowish colour; at the second moult they become green with paler coloured spines, each tipped with bright red. A choice of many shrubs were given them, but although they ate plum and sallow they left these for gooseberry.

Cecropian Silk-Moth (Samia Cecropia).-This species emerged through the month, and copulation was frequent. A large numbor of eggs were obtained, but many are not fertile, perhaps owing to the stock ahead, boring boon interbred. Young larva hatched on the 14th instant, and are growing well. Food-plant, plum.

AILANTHUS Silk-Moth (Attacus Cynthia).-This species commenced to emerge towards the end of the month, but only four specimens have yet appeared. It is usually the latest species of all. 
Perny's SIlk-MOTH (Attacus Pernyi).-Perfect insects of this species were on view throughout the month. Fertile eggs were obtained, which commenced to hatch on the zoth instant, and are doing well. Food-plant, oak.

TUSSEH SILK-MOTH (Attacus mylitta).-This species commenced to emerge on 28 th instant, a beautiful male being bred; on the following day a male and female emerged. Eggs were obtained, which are probably fertile.

Great Atlas Moth (Attacus Atlas).---Throughout the latter half of the month specimens of this species have emerged, and many fine ones have been preserved. Eggs will probably be obtained later; there are many more still to come out.

INDIAN MOON-MOTH (Actias selene). - This first specimen of this species emerged on the last day of the month.

AMERICAN Moon-Moth (Actias luna).--During the early part of the month specimens of this species emerged. Eggs have been obtained, but it is doubtful if they are fertilised.

Promethean Silk-Moth (Telea Promethea).-The cocoons of this species have as yet only produced a large ichneumon fly (Ophion). Many visitors have evinced great interest on seeing these large parasites produced from externally perfectly-formed Lepidopterous cocoons and internally stout well-made oval cocoons of the $\mathrm{Hy}$ menoptera.

JAPANESE OAK SILK-MOTH (Antherae Yama-mai).The larvæ of this species produced from eggs have done fairly well; many are now nearly full fed and about to spin. Food-plant, oak.

Besides these fine silk-moths, which are in many cases likely to be of economical value, Mr. Watkins has succeeded in breeding during the past month examples of many of the finer European butterflies, such as the swallow-tail, orange-tip, black-veined white, and $A p a-$ tura ilia, not to mention numerous Heterocera, Hymenoptera, and Neuroptera. During the present month also many additions have been made to the series.

A guide-book to the Insectarium is in preparation, not, as we are assured, with any idea of forcing visitors to buy it, as every object exhibited is fully and perfectly labelled, but rather for the purpose of making the Insectarium better known, and getting further contributions to it from foreign parts.

DR. BESSELS" ACCOUNT OF THE "POLARIS" EXPEDITION ${ }^{1}$

D EMIL BESSELS, as most of our readers will D. remember, was the chief of the scientific department on board the ill-fated Polaris, which was sent on her memorable North Pole Expedition by the United States Government in $187 \mathrm{I}$. He finished the text of the present work in the summer of 1874 , shortly after the return of the expedition, but postponed the publication until after the appearance of the official account of the voyage, which was edited by Rear-Admiral Davis. He had the misfortune to lose the greater part of his journal and many other papers in his luggage during a railway journey in Scotland.

The remarkable story of the Polaris Expedition is well known. Including Captain Hall, the commander of the expedition, the entire number of persons on board the Polaris was thirty-three. Of these eight were Esquimaux, consisting of two married couples and their four chitdren, three littlogirls of ten, eight, and three years of age, and a boy of six. Another boy, who was named Polaris, was born during the voyage in Polaris Bay, on board the vessel. Two of those on board, besides Dr. Bessels, were scientific men, namely, Messrs. R. D. W. Bryan, astronomer, and Friedrich Meyer, meteorologist. I "Die amer:cnische Nor'pol Frperition," von Emil Bessels. I eipzig
W. Engelmann, I\&79.
The highest point reached by the Polaris was lat. $82^{\circ} 26^{\prime} \mathrm{N}$. at the northern mouth of Robeson Channel. After being beset by ice and having been nipped sufficiently to render her extremely leaky, the ship was moored for the winter about forty miles south of this point in Thank God Harbour, on the east side of Robeson Channel, to the north of Petermann Fjörd. Several sledge expeditions were made from this point, but without reaching a higher latitude than that attained by the ship. Capt. Hall died on board on November 8 . In the following summer attempts were made in vain to push further northward, and it was found the ship leaked so badly that it was necessary to return homewards. The ship became beset in the ice on August 16 , and remained thus, drifting southwards with the field, suffering constantly from ice-pressure, until October 15 , when it was in such jeopardy from the ice-movements that most of the provisions and stores of all kinds and all the boats were passed out on to the ice. The ice parted suddenly, and drifted away from the ship with nineteen persons upon it, including all the Esquimaux, whilst fourteen, and amongst them Dr. Bessels, remained on board. This took place at night. The castaways remained upon the ice 196 days, suffering terrible hardships, and having drifted to the coast of Labrador, were there picked up by a sealing. ship, even the children having survived. They saw the Polaris in shore at the commencement of their long journey, and wondered their comrades did not come to their assistance, not knowing that the ship was practically a wreck, and abandoned. Those left on the ship at

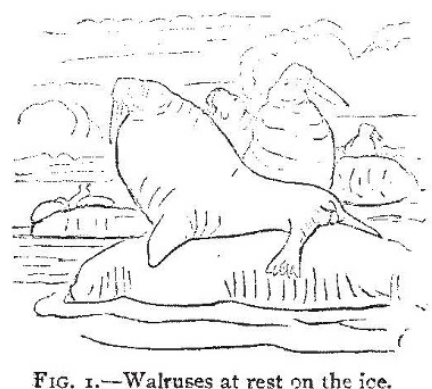

the parting of the ice, keeping the leaking ship with difficulty afloat, and unable to see anything of those on the ice, got ashore near Cairn Point in the middle of Smith's Sound, and having wintered there in company with some Esquimaux families, built some boats from the wreck, and travelling south partly in these, partly on the drift-ice, were picked up in the west of Melville Bay by a whaler, the Ravenscraig, on June 23. Thus all engaged in the expedition, excepting Capt. Hall, got back in safety.

All this is related by Dr. Bessels in a most graphic and highly interesting style, and his book is filled besides with interesting accounts of the habits of animals met with, the condition of the vegetation of the region explored, the mode of life of the Esquimaux, meteorological and other scientific observations. We shall touch on a few of these. At Fiskernæs, on the south-west Greenland coast, the author turned over some of the kitchen middens of the Esquimaux, such as are now formed in front of each hut. In a very short time remains of all the eatable vertebrates of the Greenland fauna are to be foumd in them, and in many cases it would not be difficult to fix the season at which the deposis were mace, for in places are found scarcely anything but bird-remains, in other places those of fish, in others those of mussels. Many good dogs' stulls and a number of marrow bones of seals broken for their marrow were found in the middens. At the same place one of the sailors of the Polaris nearly lost his life by attempting to perform the feat which most of the Esquimaux accomplish with such ease, of turning their kajak upside down without leaving 